\title{
UKRAINIAN PROTESTANT MUSIC TRADITION: GENESIS, HISTORICAL MILESTONES, MODERN STAGE
}

\section{Zosim O. L.}

\section{INTRODUCTION}

Ukrainian Protestant music is the least explored today. The main reason for the lack of interest of scientists in this layer of Ukrainian music is due to the historical development of Christianity in Ukraine, where Protestantism has never been a leading denomination. If Ukrainian spiritual Orthodox and Greek Catholic music was studied from the perspective of style and genre evolution, the most prominent composer from Baroque to the present are considered, then Roman Catholic and Protestant music that sounded and today sounds in the Ukrainian cultural space, practically does not fall into the field of view researchers, because traditionally these faiths are not considered Ukrainian. In historical terms, one can agree with the last postulate, but today representatives of the Roman Catholic and Protestant denominations do not belong to national minorities, as it was a few decades ago. Today music with texts in the Ukrainian language for these faiths is created primarily by representatives of the titular nation and it is one of the components of modern Ukrainian musical culture.

If Roman Catholic music, performed in the Ukrainian language, has a relatively short history - about thirty years, then Protestant for more than a hundred years. During this time, a whole galaxy of composers appeared, which, based on the traditions of Protestant music and national cultural traditions, created a rich repertoire, which today is the basis for Protestants of various denominations.

Articles by O. Klokun ${ }^{1}$ are devoted to contemporary Protestant music; an analysis of the repertoire of various Protestant churches is placed in the author's monographs ${ }^{2}$, where some Protestant collections were described. Due to the huge amount of practically unexplored material, it became necessary to

${ }^{1}$ Klokun O. (2004) Funktsionuvannya tserkovnukh pisnespiviv v interkonfesiynomu prostori [Functioning of church songs in interfaith space]. Doslidzhennya. Dosvid. Spohady [Research. Experience. Memoirs]. Kyiv, vol. 5, pp. 38-48; Klokun O. (2005) Problema khudozhnyoyi tsilisnosti v konteksti khrystyyans'koyi bohosluzhbovoyi muzyky Kyyeva [Problem of artistic integrity in the context of Christian liturgical music in Kyiv]. Naukovyy visnyk Natsional'noyi muzychnoyi akademiyi Ukrayiny imeni P. I. Chaykovs'koho [Scientific Herald Tchaikovsky National Music Academy of Ukraine]. Kyiv, vol. 51, p. 107-112.

${ }^{2}$ Zosim O. L. (2016) Ukrayins'ka dukhovna pisennist' kintsia XIX - pochatku XXI st.: osnovni tendentsiyi rozvytku [Ukrainian spiritual song of late $19^{\text {th }}$ - early $21^{\text {st }}$ centuries: the main trends of development]. Istoriya, teoriya ta praktyka suchasnoyi humanitarystyky [History, theory and practice of modern humanities]. Melitopol': Lyuks, pp. 190-206; Zosim O. L. (2017) Skhidnoslov'yans'ka dukhovna pisnia: sakralnyy vymir [Eastern Slavic spiritual song: sacred dimension]. Kyiv: NAKKKiM. 
outline the general line of development of Ukrainian Protestant music in its integrity, indicating its specific features, its connection with the national tradition, and also to show its differences from the musical tradition of traditional Ukrainian Christian denominations.

\section{Genesis and formation of Ukrainian Protestant music}

Various Protestant currents came to the territory of the Polish-Lithuanian Commonwealth, which included Ukrainian lands, almost immediately after their appearance. In the 1520-1540s. in Volyn, Cholm land, Podlasie and Galicia the first Lutheran communities emerged. Lutheran teachings became quite popular among merchants, bourgeois and artisans, among whom the German colonists predominated, while among the Ukrainian gentry there were few Lutherans. The reason for the lack of popularity of Lutheranism in the Ukrainian environment was its close connection with German culture ${ }^{3}$.

The greatest distribution in the territory of the Polish-Lithuanian Commonwealth, especially among the gentry, was Calvinism. Some changes were made to the original doctrine that mitigated this doctrine (the dogma of predestination, extreme asceticism), and in this form Calvinism was supported by the gentry, which saw in it a way of joining the cultural values of the West. Calvinism received special distribution in the Belz Voivodeship, Cholm land, in the Sanok and Przemyśl lands, in Podolia ${ }^{4}$.

The anti-trinitarian movement was popular in the Kyiv region and Volyn. Anti-Trinitarians separated from Calvinists in the 1560s. and due to its democratic nature it has embraced different sections of the population bourgeois, peasants, gentry, which are from the 1570s. began to dominate. Since the late 1690s. the Italian emigrant Faustus Socyn led the anti-trinitarian movement in the Polish-Lithuanian Commonwealth, and socinianism, as the official ideology of the Polish gentry, was also approved by the Ukrainian ${ }^{5}$. If Calvinism was popular among the gentry, which was far from Orthodoxy, then anti-Trinitarianism, thanks to its teachings, found its followers among people who were still closely associated with Orthodoxy, and, consequently, with Ukrainian culture ${ }^{6}$. Thus, Bible books were translated into UkrainianBelarusian book language and edited in accordance with one or another Protestant doctrine, and among such publications was the famous Peresopnytsia

${ }^{3}$ Lyubashchenko V. (1995) Istoriya protestantyzmu v Ukrayini [History of Protestantism in Ukraine]. Lviv: Prosvita, p. 86.

${ }^{4}$ Kolodnyy A., Yarots'kyy P. (ed.) (1999) Istoriya relihiyi v Ukrayini [History of religion in Ukraine]. Kyiv: Znannya, p. 342-344.

${ }^{5}$ Ibid, p. 345-348.

${ }^{6}$ Ibid, p. 351. 
Gospels, where the non-Orthodox tendency was especially clear in the notes to the text ${ }^{7}$.

The active development of Protestantism in the Ukrainian lands of the Polish-Lithuanian Commonwealth was interrupted in the middle of the $17^{\text {th }}$ century. In the new historical conditions, these teachings ceased to meet the needs of the masses, mainly due to some elitism, and the Polish and Ukrainian gentry began to turn to their traditional denomination - Catholicism and Orthodoxy. After the uprising of Bohdan Khmelnitsky, Calvinists and antiTrinitarians almost completely ceased their activities not only in the Hetman region, but also in Poland, where these movements were also banned, although for other reasons ${ }^{8}$.

The active development of Protestantism in the Ukrainian lands of the Polish-Lithuanian Commonwealth falls on the period of the middle of the $16^{\text {th }}$ century - middle of the $17^{\text {th }}$ century. During this time, a huge amount of Protestant literature was published in neighboring Poland, including numerous cantionals and songbooks. As for the Ukrainian-Belarusian lands of the PolishLithuanian Commonwealth, the situation here is somewhat different. Despite the significant number of Ukrainian Protestant communities and the significant influence of the ideas of Protestantism on Ukrainian cultural and religious thought, there were not so many Protestant publications in the territory of modern Ukraine. If we talk about the musical tradition of the 16 - early $17^{\text {th }}$ century, today we do not have at our disposal a single handwritten or printed songbook with an early Protestant repertoire. The only information was preserved about the Protestant, apparently Lutheran, songbook of the late $16^{\text {th }}$ century, which was stored in the library named after Edward Raczyński in Poznan, and is now lost. In it, for evidence, about 50 songs were translated, translated from German into the Ukrainian-Belarusian book language ${ }^{9}$. Although we, unfortunately, will not be able to analyze the repertoire of this book, there is one momentous point: we are talking about translation songs, and not about compositions in German or Polish, intended primarily for the nonUkrainian population. Apparently, the translators of the songs were engaged in writers - professionals or amateurs belonging to one or another Protestant denomination. That is why the texts of Protestant songs were close to contemporary poetry, just as later Baroque poetry significantly influenced the development of Orthodox and Uniate song of the $17-18^{\text {th }}$ centuries. In the

\footnotetext{
${ }^{7}$ Florovskyy G., prot. (1983) Puti russkogo bogosloviya [Ways of Russian Theology]. Paris: YMCA-PRESS, p. 34.

${ }^{8}$ Kolodnyy A., Yarots'kyy P. (ed.) (1999) Istoriya relihiyi $v$ Ukrayini [History of religion in Ukraine]. Kyiv: Znannya, pp. 351-353.

${ }^{9}$ Medvedyk Yu. (2006) Ukrayins'ka dukhovna pisnia XVII - XVIII st.: [Ukrainian spiritual song of the $17^{\text {th }}-18^{\text {th }}$ centuries]. Lviv: UKU, p. 76.
} 
$18^{\text {th }}$ century we find another example of the appeal to Lutheran hymns: the theologian, translator and preacher Simon Todorsky, who was educated at the Kyiv-Mohyla Academy and the University of Halle, translated several German songs into Ukrainian book language with baroque syllabic verses. True, these translations did not affect the development of Ukrainian religious poetry, since they were known only to a narrow circle of lovers ${ }^{10}$. Also, as an Orthodox bishop, Simon Todorsky did not plan to perform these works in Lutheran services, and he perceived his work as a way of acquainting the Orthodox with the highest works of Lutheran poetry.

If we talk about the early Protestant songs of the Polish-Lithuanian Commonwealth, in particular its eastern part, it is interesting to compare the Ukrainian and Belarusian Protestant musical traditions. Thanks to the support of Calvinism that came to the Commonwealth from Prussia, which was then part of it, Mikołaj "the Black" Radziwiłł (1515-1565), many Calvinist churches, as well as schools and printing houses, were erected on the Belarusian lands of the Grand Duchy of Lithuania. That is why the first printed songbooks in the East Slavic lands were published on the territory of Belarus, and these were just Protestant publications. Their main distinguishing feature is the exclusively Polish-speaking repertoire, however, at the same time, these publications cannot be considered fully Polish, since they were used by the Belarusian gentry, and, most likely, Ukrainian.

The first Calvinist channel published outside the territory of modern Belarus was the publication "Songs of the Glory of God" ("Pieśni chwał Boskich"), which was published in Brest in 1558 and, due to this, it was called the Brest cantional. Only a fragment has reached us from this book - twelve songs, of which only ten have been completely preserved. However, some of them could be included in the publication of Jan Seklucjan's cantional "Christian Songs" ("Pieśni chrześcijanskie"), published in Koenigsberg in 1559. The Nesvizh cantional in 1563 was repeatedly reprinted in Vilnius in 1581, 1594, 1598 and 1600 , and these editions are known as Vilnius cantionals. In the $17^{\text {th }}$ century the cantionals were published at the Calvinist printing house in Lubcha ${ }^{11}$.

Apparently, a number of these or similar publications could not have been known on Ukrainian lands, bearing in mind the need for a musical component in worship or a repertoire of spiritual content that was performed in everyday life. However, there is no need to talk about any publishing centers

${ }^{10}$ Medvedyk Yu. (2006) Ukrayins'ka dukhovna pisnia XVII - XVIII st.: [Ukrainian spiritual song of the $17^{\text {th }}-18^{\text {th }}$ centuries]. Lviv: UKU, pp. 118-119.

${ }^{11}$ Saladukhin A. M. (2006). Pratestantski kantsyyanal na Belarusi u XVI - pershay palove XVII stagoddzya [Protestant Cantional in Belarus in the $16^{\text {th }}-$ first half of the $17^{\text {th }}$ century]. Vestsi Belaruskay dzyarzhaunay akademii muzyki [Bulletin of the Belarusian State Academy of Music]. Minsk, vol. 6, pp. 11-14. 
like Belarus. This is one of the differences between Ukrainian and Belarusian Protestant songs: in the Belarusian tradition it is represented more widely and developed more consistently, but the Protestant spiritual song at that stage of development never used the Ukrainian-Belarusian book language, which is typical for the Ukrainian tradition. Also in Belarus, Calvinist publications were predominantly printed.

Concluding the conversation about early Ukrainian Protestant music, I would like to note first of all the priority of the genre of spiritual songs, which, unlike other faiths, became the main, though not the only, genre of Protestant liturgical chants. The lack of sources does not allow reconstructing the repertoire of the second half of the $16^{\text {th }}$ - ealy $17^{\text {th }}$ century, but even those few data allow us to identify the specifics of Ukrainian Protestant music - the cultivation of a translated repertoire, primarily a song distributed through handwritten songbooks, the development of several, not just one Protestant traditions (Lutheranism, Calvinism, anti-Trinitarianism). These features became the foundation of the national spiritual song tradition of the $17-18^{\text {th }}$ centuries, which developed in other confessional conditions, and also influenced the further development of Protestant music in the $20^{\text {th }}$ century. in new historical conditions.

\section{Ukrainian Protestant music of the 1920-1980s.}

Since the second half of the $17^{\text {th }}$ century and until the end of the $19^{\text {th }}$ century the development of Protestant music in Ukraine was suspended. This does not mean that there were no Protestant communities in the country at all, but they consisted mainly of representatives of national minorities. Thus, $\mathrm{T}$. artynyuk in his works describes the musical culture of the Priazovian Mennonites who were resettled from Prussia to the Ekaterinoslav province in the late $18^{\text {th }}$ century, indicating that choral singing in German was cultivated in these communities ${ }^{12}$. However, the Mennonite tradition did not affect either the development of Ukrainian Orthodox sacred music, or the music for the worship of subsequent generations of Ukrainian Protestants.

A new round of development of Ukrainian Protestant music, already on the territory of the Russian Empire, began at the turn of the $19^{\text {th }}$ and $20^{\text {th }}$

${ }^{12}$ Martynyuk T. V. (2002) Muzychna kul'tura menonitiv-pereselentsiv do terytoriyi suchasnoyi Zaporiz'koyi oblasti v XIX - na pochatku XX st. [Musical culture of Mennonite migrants to the territory of the modern Zaporizhzhya region in the $19^{\text {th }}-$ early $20^{\text {th }}$ centuries]. Teoretychni ta praktychni pytannya kul'turolohiyi [Theoretical and practical issues of cultural studies]. Melitopol': Sana, vol. VI, pp. 61-73; Martynyuk T. V. (2014) Kharakterystyka kul'tury pryazovs'kych menonitiv XIX - na pochatku XX st. [Characteristics of the culture of Azov Mennonites of the $19^{\text {th }}$ - early $20^{\text {th }}$ centuries]. Karpats'kyy kray. Naukovi studiyi z istoriyi, kul'tury, turyzmu [Carpathian region. Scientific studies in history, culture, tourism], vol. 1 (4), pp. 5-14. 
centuries, when, due to liberalization of politics, non-Orthodox Christians gained freedom of religion, and the Protestant communities, among which the Baptists were the most numerous at that time, began to actively print their literature, including music and liturgical. The first to launch their publications were Russian Protestants. In 1902, the "Gusli" (“Гусли") collection, prepared by Ivan Prokhanov, was published. This book contained only texts of spiritual chants, most of which were translated by Prokhanov himself. Only a quarter century later, already in the USSR, musical editions of this collection appeared (1927-1928), they were called the “Ten Book” (“Десятисборник”) and consisted of three volumes, which included ten books: the first volume included the collection "Gusli" ("Гусли"), the second "Christian Songs" ("Песни христианина”), “Туmpans” (“Тимпаны”), “Kimbala” (“Кимвалы”), “New tunes" ("Новые напевы”), the third - "Songs of the first Christians" ("Песни первых христиан”), "Dawn of life” (“Заря жизни”), "Flute of David” (“Свирель Давида”), “Songs of Anna” (“Песни Анны”), “Songs of depth” ("Песни глубины"). The value of this publication is great, it is rightly called the "Prokhanov Psalter" ${ }^{13}$, because it laid the foundation for a new tradition of church singing in the Russian Empire and the USSR, which included most of modern Ukraine. For Ukrainian Protestants, these collections were of great importance, since they became the basis for the development of their own Protestant musical tradition.

For historical reasons, the Protestant musical tradition in Ukraine in the 1920-1930s. developed simultaneously and often independently in two countries - the USSR and Poland. The first editions of Protestant (Baptist) chants were published in Kharkiv ("Harp” (“Арфа”, 1925, 1928), "Native Tunes” ("Рідні мелодіï", 1927)), and in the cities of Volyn and Galicia, as well as Poland ("The Pilgrim songs" (“Пісні паломника”, Kremenets, 1920), "Voice to Sion” (“Голос Сіону”, Lviv, 1930), "Наrp to Sion” (“Арфа Сіону”, Lviv, 1931), "Songs of the Salvated” ("Пісні спасенних", Lviv, 1937), “Treasure” (“Скарбничка", Kremenets, 1930), "Psalm Songs” ("Псалмоспіви”, Kremenets, 1937, 1939), “The Christian Songbook” (“Християнський співаник”, Lodź, 1932), “The New Christian Songbook” (“Новий християнський співаник”, Rava-Rus’ka, 1935) ${ }^{14}$. Unfortunately, most of these collections, unlike the Prokhanov ones, which are now digitized and open to the researcher, are not came to us, their search and subsequent analysis will allow us to analyze in detail the formation of Ukrainian

${ }^{13}$ Lozovskaya N. V., Fokin D. A. (2015) Muzykal’noye tvorchestvo protestantskich religioznych dvizheniy SSSR: razvitiye zhanra duchovnoy pesni [Musical creativity of the Protestant religious movements of the USSR: the development of the spiritual song genre]. Kazanskaya nauka [Kazan science]. Kazan, vol. 10, p. 60.

${ }^{14}$ Zhabko-Potapovych L. (ed.) (1954) Yevanhels'kyy spivanyk Vidrodzhennya [Gospel Songbook of the Renaissance]. Chicago: Ukrainian Evangelical Baptist Church, pp. 5-6. 
Protestant music. However, today it is already known that they were based on translations of borrowed chants, although the works of local authors were necessarily included: in the Kremenets collection "Treasure" (1930) there were a significant number of compositions translated from Russian and Polish, but it also included the works of its composer D. Gerasevych and songs by local authors ${ }^{15}$. It is very likely that part of the early Baptist repertoire, thanks to the publications of the diaspora, became part of the modern Baptist liturgical tradition.

In the 1930s in Western Ukraine, a group of Greek Catholic and Orthodox priests united to reform church communities based on the ideas of Lutheranism. This church is called the Ukrainian Evangelical Church of the Augsburg Religion. Her worship is interesting in that it is based on the treason of the liturgy of John Chrysostom. The songbook of this branch of Lutheranism- "Ukrainian Evangelian Songbook” (“Український євангельський співаник”, Stanislaviv, $1933)^{16}$, which is interesting for its combination of the Ukrainian national tradition represented in the publication by a song repertoire created by Orthodox and Greek Catholic authors, with Lutheran church dogma and cultural tradition, has survived.

As for the publications of Soviet Ukraine, in the late 1920s. there was an active development of the repertoire in the Ukrainian language, which was a consequence of the Ukrainianization carried out at that time. The pastor, poet, preacher and editor of the Baptist magazine of Ukraine I. Kmeta-Yefimovich helped the choirs to sing Ukrainian songs from the collection "Harp" (“Арфa") at divine services ${ }^{17}$. At the same time, Pentecostals cultivated the Russianlanguage repertoire in connection with the wishes of the then leadership, and Adventists performed hymns in Russian and German at divine services ${ }^{18}$.

The free development of the Protestant tradition was interrupted in Soviet Ukraine in the beginning, and in the western - in the late 1930s. The center for the creation of church hymns in the post-war period moved to the diaspora - the countries of Europe, the USA, Canada, Latin America. These publications helped preserve the gains that were achieved by Ukrainian Protestants. If you collect all the collections published in all countries, and there will be a significant number of

${ }^{15}$ Kwach M. (2011) Poyava ta rozvytok yevanhels'kykh hromad na Kremenecchyni u mizhvoyennyy period (1918-1939 rr.) [Emergence and development of evangelical communities in Kremenets region during the interwar period (1918-1939)]. Ukrayins'ke religiyeznavstvo [Ukrainian Religious Studies]. Kyiv, vol. 58, p. 47.

${ }^{16}$ Yarchuk T. (ed.) (1933) Ukrayins'kyy yevanhels'kyy spivanyk [Ukrainian Evangelian Songbook]. Stanislaviv: U. E. A. M. Rada.

${ }^{17}$ Ihnatusha A. Ye. (2001) Polityka ukrayinizatsiyi u viddzerkalenni protestants’koyi presy 20-kh rr. XX st. [The Politics of Ukrainization in Reflection of the Protestant Press of the 1920s.]. Naukovi pratsi istorychnoho fakul'tetu Zaporiz'koho derzhavnoho Universytetu [Scientific works of the History Department of Zaporizhzhya State University]. Zaporizhzhya, vol. XIII, p. 94.

${ }^{18}$ Ibid,, pp. 98-100. 
them, and their location and description can form a complete picture of the development of the Ukrainian Protestant liturgical tradition. For now, we'll mention only a few that became the basis of the updated national repertoire, which was already heard at church meetings in independent Ukraine, among them the "Voice of the Gospel” (“Голос Свангеліï", Saskatoon, Canada, 1958)" "Gospel Songbook of the Renaissance” (“Свангельський співаник Відродження”, Chicago, USA, 1954) ${ }^{20}$ and others. At this time, many authors' collections appear. One of the most prolific diaspora Baptist authors was Serhiy Bychkovs'ky (1913-1998). A native of Volyn, he began his ministry in a church choir. The composer published his first editions in Western Ukraine, which was then part of Poland, as well as in Poland ("Source of Spiritual Songs" (“Джерело духовних пісень”, 1933), “Star” (“Зоря”, Warsaw, 1936), “Songs of Awakening” ("Пісні пробудження", Warsaw, 1941, 1943)), later in Germany ("Melody of the Wanderer" ("Мелодії скитальця", 1947), “A Native Song in a Foreign Land” (“Рідна пісня на чужині”, 1948)), Canada (“New Songs” (“Нові пісні", Toronto, 1953), the three-part companion "Songs of Grace" ("Пісні ласки”, Toronto, 1960-1970s), after Ukraine gained independence, his compositions began to be published in the homeland (songwriter "Songs of the Salvated" ("Пісні спасених", Lviv, 1992).

However, one cannot say that the Protestant tradition developed only outside of Ukraine. Despite the persecution of the Baptists, many excellent works were written during this period in the USSR (biographies of the authors can be found on the website ${ }^{21}$ ). Among the most significant Ukrainian Protestant composers are Dmytro Voyevoda (born 1928), Pavlo Datsko (1884-1939), Artemy Kazimirsky (1905-1974), Serhiy Batsuk (1910-1983). Thanks to their creativity, a powerful branch of Protestant music was realized in Ukraine, which combined the traditions of Baptist singing with national musical sources.

Let us consider in detail the features of the Protestant repertoire in the context of its genre and style landmarks, as well as changes in borrowed texts in accordance with confessional priorities.

Protestant music formed its original genre system, which was very diverse and depended on the creed and traditions of a particular denomination. Lutherans and Anglicans have largely preserved the features of Roman Catholic worship, the "new" Protestants - Baptists, Pentecostals, Adventists - created their own system of genres based on the text of the Holy Scriptures, namely,

${ }^{19}$ Ulyanyuk P. (ed.) (1958) Holos Yevanheliyi [Voice of the Gospel]. Saskatoon: publisher's own work.

${ }^{20}$ Zhabko-Potapovych L. (ed.) (1954) Yevanhels'kyy spivanyk Vidrodzhennya [Gospel Songbook of the Renaissance]. Chicago: Ukrainian Evangelical Baptist Church.

${ }^{21}$ Istoriya khristianskikh gimnov [History of Christian hymns]. Retrieved from: http://hymns.us.to/ (accessed 05 October 2019). 
fragments of the Epistles of the Apostle Paul (Colossian 3:16, Ephesians 5: 19),

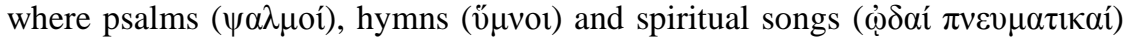
are mentioned. Over the long history of Christian music, its genre system has changed and transformed many times, so the songs of the Baptists or Pentecostals are little similar to the songs of the early Christians, and were based on the musical genres and forms of their time, although quite simplified.

The genre system of Protestant music, especially its new branches, was significantly different from both Orthodox and Catholic. The new Protestant churches cultivated two types of singing - community and professional. For community performance, the genre of a one-voice stanza song, performed with instrumental accompaniment, became central. In the songbooks, these compositions were placed in the form of texts without notes, since the melodies were known to all parishioners. However, the Baptists also had chants of more complex forms performed by the choir of the community, which included professionals. Such compositions began to be called hymns and were performed by the choir a cappella or accompanied by a piano or other instruments. Choral hymns could be quite simple - in a stanza (verse) form, and then they came closer in form to songs performed by the community. However, there were often works in which cross-cutting development prevailed, and the composition was divided into several contrasting fragments that illustrated the test of chants. Such compositions were close to choral concerts - a genre popular in the Ukrainian Orthodox tradition. However, one cannot say that it was the Ukrainian tradition that became the basis of the developed polyphonic compositions among the Baptists. In their work, they relied on forms cultivated in $19^{\text {th }}$ century American Baptist music, which turned out to be typologically close to the national church tradition, which could not but affect Ukrainian Baptist composers. In addition to choral compositions characteristic of liturgical singing, at the beginning of the $20^{\text {th }}$ century in church practice genres borrowed from secular music were also used. For Ukrainian music an extensive genre system was not characteristic at that time, while "Gusli" ("Гусли”) by I. Prokhanov (1927), as the publishers themselves indicate, included hymns for female and male choirs, hymns for solo performance, duets, solo chants, solo chants and duets with choral completion, melodclamations and hymns for general singing. Solo chants were close to romances or arias, from which they were distinguished by a religious text. If we talk about the Ukrainian tradition, then there are practically no solo compositions close to romance or aria, however, in choral scores, solo episodes are often performed, accompanied by a chorus or instrument. The genre music system of Baptists, and later Pentecostals and Adventists, consisting of more complex form and musical language choral hymns and simpler community songs, has become universal for new Protestant churches and is still used today. 
The style of Baptist music was not particularly innovative, exceptions were very rare, such as, for example, modern solo chants in the collection of "Gusli" ("Гусли”) by I. Prokhanov. However, on the whole, Protestants in their work during this period are guided by the classic-romantic style as universal and acceptable for most parishioners. Choral four voices with a chord texture, slow or moderately fast tempo, solemn or mournful intonations (depending on the content of the chant) created the condition necessary for the general prayer of the Protestant communities. As for the national component in Protestant music, it is noticeable primarily in the musical language, where songs and romances or intonations that go back to the baroque and classic stylistics of the Ukrainian choral concert are frequent.

In the Protestant musical tradition, a new type of collection of chants was formed, which differed not only from Orthodox and Catholic publications, but also from Protestants of traditional denominations. Baptist publications no longer use the calendar type of organization of the repertoire that is characteristic of liturgical books by Orthodox Christians, Catholics, Lutherans and Anglicans, but themed ones replace it, and chants can be directly grouped by topics, however they are recorded in random order at least the thematic grouping is present only virtually - in thematic and alphabetical indexes. Ukrainian Protestants in their publications focused on the traditions of structuring, tested in foreign church practice.

Particular attention in Protestant music was given to the texts of chants, since the proclamation of God's Word became the center of the doctrine of all Protestants. The texts of Protestant chants could be 1) fragments of Holy Scripture, primarily the texts of psalms, 2) original chants of Protestant authors, 3) adapted in accordance with their doctrine compositions, taken from the heritage of other Christian denominations. Almost every Baptist publication included chants of all three types, except for authors' collections. The degree of processing of texts could be different - from minor, but dogmatically important changes to a significant transformation of the original texts. As an example, we will mention the Lutheran collection "Ukrainian Evangelian Songbook" ("Український євангельський співаник", Stanislaviv, 1933) ${ }^{22}$, in which the compiler of the collection, pastor Theodor Yarchuk, placed a number of famous Ukrainian carols in the group of Christmas songs, partially changing their text not only for the purpose of modernization, but also bringing it closer to Lutheran worldview.

Summarizing our knowledge regarding this stage of development of Ukrainian Protestant music, we point out the following points. The revival of Protestant music took place only in the $20^{\text {th }}$ century, before that it developed as

${ }^{22}$ Yarchuk T. (ed.) (1933) Ukrayins'kyy yevanhels'kyy spivanyk [Ukrainian Evangelian Songbook]. Stanislaviv: U. E. A. M. Rada. 
a musical tradition of national minorities. A new stage in the development of Ukrainian Protestant music was associated with the largest Baptist denomination at that time, however, other Protestant denominations also developed - Lutherans, Adventists, etc. Ukrainian Baptists in their work were guided by the Western and Russian repertoire in its genre and style integrity, they relied on their national tradition through the use of famous Ukrainian chants, primarily songs, filling the musical text of their compositions with characteristic Ukrainian romantic song-romance intonations, as well as appeal to the tradition of the choir concert of the Baroque and Classicism.

\section{Ukrainian Protestant music at the present stage}

After the declaration of independence of Ukraine in 1991 and even somewhat earlier, from the late 1980s, after the end of the persecution of Protestant churches, we are witnessing a revival of the interrupted Protestant musical tradition. New communities appear, publishing houses are opening that print Protestant literature, including collections of liturgical chants. New editions are based on collections published in the 1920-1930s. both in the diaspora and in musical compositions written in Ukraine during the Soviet era.

Among the Protestant denominations significant for Ukraine, we will single out the Lutheran as historically the first and such, the development of which has not been interrupted in the history of Ukraine. Today, three Lutheran associations coexist in Ukraine - the German Evangelical Lutheran Church of Ukraine, its branch of the Synod of the Evangelical Lutheran Churches of Ukraine and the Ukrainian Lutheran Church. The first focuses primarily on Lutherans of German descent and on German national tradition. It is less included in the process of Ukrainization, and today, among the many Protestant branches, only representatives of German Lutherans have not released a collection of church songs in Ukrainian. Ukrainian Lutheran Church, which arose in the 1930s. in Western Ukraine, it focuses primarily on the Ukrainian national tradition, and its motto is "Through the Reformation - Ukrainization!". On the website of the Ukrainian Lutheran Church $^{23}$ performed by the choir, you can listen to the modern liturgical repertoire, which includes both chants from the liturgy of John Chrysostom ("Bless My Soul, the Lord” ("Благослови, душе моя, Господа”), “The Only Begotten Son” (“Сдинородний Сине”), “Cherubic” ("Херувимська"), as well as hymns from the publication "Ukrainian Evangelian Songbook” (“Український євангельський співаник”, Stanislaviv, 1933)

${ }^{23}$ Ukrayins'ka lutherans'ka tserkva [Ukrainian Lutheran Church]. Retrieved from: http://ukrlc.org/ (accessed 05 October 2019).

${ }^{24}$ Yarchuk T. (ed.) (1933) Ukrayins'kyy yevanhels'kyy spivanyk [Ukrainian Evangelian Songbook]. Stanislaviv: U. E. A. M. Rada. 
written by Theodor Yarchuk. Note that this branch of Lutheranism is one of the most nationally oriented.

No less significant for Ukraine is the Baptist church, which today is the largest of all Protestant ones. Let us single out from a significant number of publications the notated collections of "Gospel Song” (“Свангельська пісня", Kyiv, 1988) ${ }^{25}$ and its updated version of "Gospel Songs" (“Евангельські пісні”, Kyiv, 1997) ${ }^{26}$. These two fundamental collections of the Baptist repertoire contain chants written throughout the $20^{\text {th }}$ century different authors. It is significant that these publications, despite the proximity of their names, contain a different repertoire, which allows you to get acquainted with a fairly complete picture of modern Baptist chants in Ukrainian. In addition, in the 2000s. notated and non-notated books began to appear under the names "Psalm Songs" (“Псалмоспіви”) and "Gospel Songs” (“Свангельські Пісні”), in which the number of works is constantly growing. We also point out the magazines where at one time new songs were published ("Songs of Praise " ("Пісні хвали"), which contained the application in the form of a cassette or a CD with music. In addition, Ukrainian Protestants, especially in the eastern and southern regions of Ukraine, today widely use Russian Protestant publications, which are based on "Gusli” (“Гусли”) by I. Prokhanov.

To characterize the modern repertoire, let us dwell on two aspects: the adaptation of the texts of Orthodox and Catholic chants for Protestant services and the stylistic variety of modern Protestant chants. The first aspect is disclosed in sufficient detail in her article by O. Klokun ${ }^{27}$, where the researcher not only names Orthodox and Catholic works that sound in the churches of Kyiv Lutherans, Baptists, Adventists, but also clearly shows the textual and accordingly melodic transformations that occur with works from other faiths, come to the Protestant repertoire. Among the composers whose compositions sound at Protestant services are the compositions of I. S. Bach, G. F. Handel, W. A. Mozart, L. Beethoven, F. Schubert, D. Bortnyansky, P. Tchaikovsky, M. Ryms'kyy-Korsakov, P. Chesnokov and many others. As a rule, these are parts of Catholic and Orthodox liturgical chants, spiritual oratory, cantatas, choral concerts, spiritual songs in a choral arrangement. In cases where the theme of the original chants did not correspond to church dogma (most often

${ }^{25}$ Republican Council of Evangelical Christians Baptists (1988) Yevanhels'ka pisnia [Gospel Song]. Kyiv: Republican Council of Evangelical Christians Baptists.

${ }^{26}$ Kreshchuk O. (ed.) (1997) Yevanhels'ki pisni [Gospel Songs]. Kyiv: All Ukrainian Union of Evangelical Baptist Associations.

${ }^{27}$ Klokun O. (2004) Funktsionuvannya tserkovnukh pisnespiviv v interkonfesiynomu prostori [Functioning of church songs in interfaith space]. Doslidzhennya. Dosvid. Spohady [Research. Experience. Memoirs]. Kyiv, vol. 5, pp. 38-48. 
this happens when the Virgin Mary chants are taken as the basis), these fragments were simply discarded or re-texted.

The classical Protestant repertoire was thus replenished with works belonging to the world or national classics. For Protestant music, confessional origin does not matter, the main thing is that the chant should be in line with doctrine and serve as an edification in faith for a Christian. From the point of view of the genre system, we relate such hybrids to the genre of hymns, and in particular to their non-trophic variety. In this regard, we note that the openness of the Protestant genre system, which consists of two types of chants, makes it possible to adapt almost any music to liturgical needs.

Another aspect that needs to be highlighted is the style of modern Protestant music. Modern sound space is extremely pluralistic and is represented by music of all directions, styles, genres and eras. The music of Christian worship, which was traditionally the most conservative, was no exception, and in the process of its renewal Protestants were the most innovative. Today, the Protestant music of most denominations can be divided into two types - traditional, based on classic-romantic traditions, and modern, which has absorbed the intonations and rhythms of modern entertainment music. If the previous stage of the development of Protestant music relied solely on the classic-romantic tradition, creating the basis of the Protestant repertoire, which has still not lost its relevance, today modern Protestant chants of the "lite" style gradually, if not supplant the church classics, acquire signs of symbolism, since it's they appear in the minds of people who are far from Protestantism. This was partly facilitated by the American tradition, especially the spirituals and gospels genres, which violated the boundaries between the concentrated, contemplative and ecstatic type of Christian music, and today have become part of the modern music commercial industry.

Nowadays, in Protestant services, music of different styles sounds - both classical and modern. As a rule, they are not combined in one service, so on Sunday in Christian communities there are several services where the older generation attend morning and afternoon, and youth attend evening ones. It is on youth services that music is based on the rhythms of modern pop and rock music. Such compositions are accompanied by guitars, sometimes by a vocalinstrumental ensemble with electric guitars, synthesizers, percussion, etc.

Now "youth" chants have become popular among Christians of various faiths, where they moved from the repertoire of Protestants. You can even talk about the significant influence of Protestant music on other faiths, which is very significant, if you do not forget that Protestantism is the youngest branch of Christianity. The new musical style today has smoothed out confessional differences, at least in its musical part, and in this the historical significance of modern Protestant, including Ukrainian, music. 


\section{CONCLUSIONS}

We summarize briefly, highlighting the main features of the Ukrainian Protestant musical tradition.

1. Protestantism is not the leading Ukrainian Christian denomination, but it has a history that is not much shorter than the history of the entire Protestant movement. Moreover, all Protestant denominations, due to insufficiently significant influence on the national culture, developed in parallel, without the priority of a particular denomination.

2. The history of Ukrainian Protestant music, as well as Ukrainian Protestantism, was not continuous. After a rapid take-off in the middle of the $16^{\text {th }}$ century a century later, Protestantism lost its significance; later Protestantism on Ukrainian lands was professed by representatives of various national minorities. The revival of nationally oriented Protestantism began only in the $20^{\text {th }}$ century, and today it is a significant enough Christian denomination for Ukraine, which has its own history, tradition and culture.

3. The development of the Ukrainian Protestant musical tradition went from borrowing foreign textual and musical samples and their adaptation to creating a Ukrainian repertoire with a pronounced musical language, based on national traditions. The emergence of its own school of composers contributed to the professionalization of Ukrainian Protestant music, which allowed us to create a repertoire that has now become classic.

4. The Ukrainian Protestant tradition has gone through all the stylistic stages of the evolution of Christian music - from the Renaissance to the postmodern, and at each stage the samples that have reached us testify to the high spiritual and professional level of its creators, their faithfulness to the tradition of their own faith, as well as concern for the development of national culture.

\section{SUMMARY}

The article analyzes the three stages of development of the Ukrainian Protestant musical tradition. Information about the first stage of the development of Protestant music $\left(16^{\text {th }}-17^{\text {th }}\right.$ centuries $)$ is extremely scarce, but even its small number indicates that Protestantism had a rather large influence on the development of Ukrainian national culture. The second and third stages ( $20^{\text {th }}$ - early $21^{\text {st }}$ century) are characterized by the stabilization of musical forms and the genre system; active stylistic dynamics can be seen, especially during the late $20^{\text {th }}$ - early $21^{\text {st }}$ century. Western tradition had the formation and development of Ukrainian Protestant music, while the songs of Ukrainian Protestants are individual, not only in connection with the creation of the original repertoire in the Ukrainian language, but also due to the filling of the musical text of their compositions with characteristic Ukrainian romantic songromance intonations, as well as appeal to the tradition of the choir concert of the Baroque and Classicism. 


\section{REFERENCES}

1. Florovskyy G., prot. (1983) Puti russkogo bogosloviya [Ways of Russian Theology]. Paris: YMCA-PRESS (in Russian)

2. Ihnatusha A. Ye. (2001) Polityka ukrayinizatsiyi u viddzerkalenni protestants'koyi presy 20-kh rr. XX st. [The Politics of Ukrainization in Reflection of the Protestant Press of the 1920s.]. Naukovi pratsi istorychnoho fakul'tetu Zaporiz'koho derzhavnoho Universytetu [Scientific works of the History Department of Zaporizhzhya State University]. Zaporizhzhya, vol. XIII, pp. 91-102 (in Ukrainian)

3. Istoriya khristianskikh gimnov [History of Christian hymns]. Retrieved from: http://hymns.us.to/ (accessed 05 October 2019) (in Russian)

4. Klokun O. (2004) Funktsionuvannya tserkovnukh pisnespiviv v interkonfesiynomu prostori [Functioning of church songs in interfaith space]. Doslidzhennya. Dosvid. Spohady [Research. Experience. Memoirs]. Kyiv, vol. 5, pp. 38-48 (in Ukrainian)

5. Klokun O. (2005) Problema khudozhnyoyi tsilisnosti v konteksti khrystyyans'koyi bohosluzhbovoyi muzyky Kyyeva [Problem of artistic integrity in the context of Christian liturgical music in Kyiv]. Naukovyy visnyk Natsional'noyi muzychnoyi akademiyi Ukrayiny imeni P. I. Chaykovs'koho [Scientific Herald Tchaikovsky National Music Academy of Ukraine]. Kyiv, vol. 51, pp. 107-112 (in Ukrainian)

6. Kolodnyy A., Yarots’kyy P. (ed.) (1999) Istoriya relihiyi v Ukrayini [History of religion in Ukraine]. Kyiv: Znannya (in Ukrainian)

7. Kreshchuk O. (ed.) (1997) Yevanhels'ki pisni [Gospel Songs]. Kyiv: All Ukrainian Union of Evangelical Baptist Associations (in Ukrainian)

8. Kwach M. (2011) Poyava ta rozvytok yevanhels'kykh hromad na Kremenecchyni u mizhvoyennyy period (1918-1939 rr.) [Emergence and development of evangelical communities in Kremenets region during the interwar period (1918-1939)]. Ukrayins'ke religiyeznavstvo [Ukrainian Religious Studies]. Kyiv, vol. 58, pp. 45-53 (in Ukrainian)

9. Lozovskaya N. V., Fokin D. A. (2015) Muzykal'noye tvorchestvo protestantskich religioznych dvizheniy SSSR: razvitiye zhanra duchovnoy pesni [Musical creativity of the Protestant religious movements of the USSR: the development of the spiritual song genre]. Kazanskaya nauka [Kazan science]. Kazan, vol. 10, pp. 59-62 (in Russian)

10. Lyubashchenko V. (1995) Istoriya protestantyzmu $v$ Ukrayini [History of Protestantism in Ukraine]. Lviv: Prosvita (in Ukrainian)

11. Martynyuk T. V. (2002) Muzychna kul’tura menonitiv-pereselentsiv do terytoriyi suchasnoyi Zaporiz'koyi oblasti v XIX - na pochatku XX st. [Musical culture of Mennonite migrants to the territory of the modern Zaporizhzhya region in the $19^{\text {th }}-$ early $20^{\text {th }}$ centuries]. Teoretychni ta 
praktychni pytannya kul'turolohiyi [Theoretical and practical issues of cultural studies]. Melitopol': Sana, vol. VI, pp. 61-73 (in Ukrainian)

12. Martynyuk T. V. (2014) Kharakterystyka kul'tury pryazovs'kych menonitiv XIX - na pochatku XX st. [Characteristics of the culture of Azov Mennonites of the $19^{\text {th }}$ - early $20^{\text {th }}$ centuries]. Karpats'kyy kray. Naukovi studiyi z istoriyi, kul'tury, turyzmu [Carpathian region. Scientific studies in history, culture, tourism], vol. 1 (4), pp. 5-14 (in Ukrainian)

13. Medvedyk Yu. (2006) Ukrayins'ka dukhovna pisnia XVII - XVIII st.: [Ukrainian spiritual song of the $17^{\text {th }}-18^{\text {th }}$ centuries]. Lviv: UKU (in Ukrainian)

14. Republican Council of Evangelical Christians Baptists (1988) Yevanhels'ka pisnia [Gospel Song]. Kyiv: Republican Council of Evangelical Christians Baptists (in Ukrainian)

15. Saladukhin A. M. (2006). Pratestantski kantsyyanal na Belarusi u XVI - pershay palove XVII stagoddzya [Protestant Cantional in Belarus in the $16^{\text {th }}$ - first half of the $17^{\text {th }}$ century]. Vestsi Belaruskay dzyarzhaunay akademii muzyki [Bulletin of the Belarusian State Academy of Music]. Minsk, vol. 6, pp. 10-14 (in Belarusian)

16. Ukrayins'ka lutherans'ka tserkva [Ukrainian Lutheran Church]. Retrieved from: http://ukrlc.org/ (accessed 05 October 2019) (in Ukrainian)

17. Ulyanyuk P. (ed.) (1958) Holos Yevanheliyi [Voice of the Gospel]. Saskatoon: publisher's own work (in Ukrainian)

18. Yarchuk T. (ed.) (1933) Ukrayins'kyy yevanhels'kyy spivanyk [Ukrainian Evangelian Songbook]. Stanislaviv: U. E. A. M. Rada (in Ukrainian)

19. Zhabko-Potapovych L. (ed.) (1954) Yevanhels'kyy spivanyk Vidrodzhennya [Gospel Songbook of the Renaissance]. Chicago: Ukrainian Evangelical Baptist Church (in Ukrainian)

20. Zosim O. L. (2016) Ukrayins'ka dukhovna pisennist' kintsia XIX pochatku XXI st.: osnovni tendentsiyi rozvytku [Ukrainian spiritual song of late $19^{\text {th }}$ - early $21^{\text {st }}$ centuries: the main trends of development]. Istoriya, teoriya ta praktyka suchasnoyi humanitarystyky [History, theory and practice of modern humanities]. Melitopol': Lyuks, pp. 190-206 (in Ukrainian)

21. Zosim O. L. (2017) Skhidnoslov'yans'ka dukhovna pisnia: sakralnyy vymir [Eastern Slavic spiritual song: sacred dimension]. Kyiv: NAKKKiM (in Ukrainian)

\section{Information about the author:} Zosim O. L., orcid.org/0000-0001-7546-094X

Dr. hab., Associate Professor, Associate Professor of the Department of Academic and Variety Vocal and Sound Processing National Academy of Culture and Arts Management 9, Lavrska str., 03015, Kyiv, Ukraine 